\title{
Calcium balance in embryos and larvae of the freshwater-adapted teleost, Oreochromis mossambicus
}

\author{
Pung-Pung Hwang ${ }^{1,2 *}$, Ya-Ni Tsai ${ }^{1}$ and Yu-Chi Tung ${ }^{1}$ \\ ${ }^{1}$ Institute of Zoology, Academia Sinica and ${ }^{2}$ Institute of Fisheries Science, National Taiwan University, \\ Taipei, Taiwan, R.O.C.
}

Accepted: May 20, 1994

Keywords: tilapia, embryos, larvae, development, $\mathrm{Ca}^{2+}$ content, $\mathrm{Ca}^{2+}$ influx, $\mathrm{Ca}^{2+}$ efflux, skin, chloride cells

\begin{abstract}
Changes in $\mathrm{Ca}^{2+}$ content and flux, and the development of skin chloride cells in embryos and larvae of tilapia, Oreochromis mossambicus, were studied. Tilapia embryos hatched within $96 \mathrm{~h}$ at an ambient temperature of $26-28^{\circ} \mathrm{C}$. Total body $\mathrm{Ca}^{2+}$ content was maintained at a constant level, about $4-8 \mathrm{nmol}$ per individual, during embryonic development. However, a rapid increase in body $\mathrm{Ca}^{2}+$ level was observed after hatching, 12.8 to $575.3 \mathrm{nmol}$ per individual from day 1 to day 10 after hatching. A significant influx and efflux of $\mathrm{Ca}^{2+}$ occurred during development, with the average influx rate for $\mathrm{Ca}^{2+}$ increasing from $5.9 \mathrm{pmol}^{\mathrm{mg}}{ }^{-1}$ $\mathrm{h}^{-1}$ at $48 \mathrm{~h}$ postfertilization to $47.8 \mathrm{pmol} \mathrm{mg}^{-1} \mathrm{~h}^{-1}$ at 1 day posthatching. The skin was proposed as the main site for $\mathrm{Ca}^{2+}$ influx before the development of gills, and the increased $\mathrm{Ca}^{2+}$ influx may be ascribed to gradual differentiation of skin surface and chloride cells during embryonic development. $\mathrm{Ca}^{2+}$ efflux was 16-56 pmol mg $\mathrm{m}^{-1} \mathrm{~h}^{-1}$ in 1-day-old larvae. The resulting net influx of $\mathrm{Ca}^{2+}, 10-12 \mathrm{pmol} \mathrm{mg}^{-1} \mathrm{~h}^{-1}$, accounted for the increased $\mathrm{Ca}^{2+}$ content after hatching. When comparing the measured and estimated ratios of efflux and influx, active transport was suggested to be involved in the uptake of $\mathrm{Ca}^{2+}$. Chloride cells, which may be responsible for the active uptake of $\mathrm{Ca}^{2+}$, started to differentiate in the skin of embryos $48 \mathrm{~h}$ after fertilization, and the density of chloride cells increased following the development. A possibility of active transport for $\mathrm{Ca}^{2+}$ in early developmental stages of tilapia is suggested.
\end{abstract}

\section{Introduction}

The ability of adult teleosts to maintain constant plasma $\mathrm{Ca}^{2}+$ levels in diverse calcium environments has been well documented (Pang et al. 1980). Freshwater teleosts actively accumulate $\mathrm{Ca}^{2+}$ from both food and surrounding medium. The gills, intestine, and kidneys are the most important sites for $\mathrm{Ca}^{2+}$ exchange between the external and internal environments. The gills, however, are believed to be the major route for direct absorption of $\mathrm{Ca}^{2+}$ from water (Perry and Wood 1985; Flik et al. 1985). Physiological studies have demonstrated that chloride cells are the sites responsible for the $\mathrm{Ca}^{2+}$ uptake in the gill of freshwater teleosts (Payan et al. 1981; Perry and Flik 1988; Marshall et al. 1992; McCormick et al. 1992; Perry et al. 1992).

Embryos and larvae of several teleosts, in which the gills or kidneys are poorly developed, have been found to be able to maintain constancy in the ion concentrations and osmolality of their body fluids

* Correspondence to: Dr. P.P. Hwang, Institute of Zoology, Academia Sinica, Nankang, Taipei, Taiwan 11529, R.O.C. 
(Alderdice 1988). The outer membrane of teleosts eggs, the chorion, is permeable to both salts and water but not to large molecules. Thus the vitelline membrane is the only effective barrier between embryos and the external medium (Eddy 1982). Similar to the adult, embryos and larvae have to face the freshwater environment which contains less $\mathrm{Ca}^{2+}$ than the body fluid. Brown an Lynam (1981) examined the mortality of brown trout, Salmo trutta, eggs incubated in freshwater with different concentrations of $\mathrm{Na}^{+}$and $\mathrm{Ca}^{2+}$ and suggested that a certain level of $\mathrm{Ca}^{2+}$ in the incubation water is of prime importance during its early development. Lee and $\mathrm{Hu}$ (1983) found that $\mathrm{Ca}^{2+}$ rather than $\mathrm{Mg}^{2+}$ is indispensable to the embryonic development of mullet (Mugil cephalus). Alderdice (1988) reported that the addition of $\mathrm{Ca}^{2+}$ and $\mathrm{Na}^{+}$to hatchery water of low ionic activity resulted in a significant reduction in mortality of chinook salmon (Oncorchynchus tshawytscha) alevins. Recently, ambient cadmium was found to inhibit $\mathrm{Ca}^{2+}$ uptake and result in death in the embryos and larvae of tilapia (Oreochromis mossambicus) (Fu and Lock 1990; Hwang et al. 1994). However, little is known about the mechanisms of $\mathrm{Ca}^{2+}$ balance in embryos or larvae. The purpose of this study was to elucidate the mechanism of $\mathrm{Ca}^{2+}$ balance in embryos and larvae of freshwater-adapted tilapia (Oreochromis mossambicus). The profile of $\mathrm{Ca}^{2+}$ content and fluxes during the embryonic and larval development were clarified, and differentiation of the skin surface and chloride cells were also studied to elucidate the possible mechanism of $\mathrm{Ca}^{2+}$ balance.

\section{Materials and methods}

\section{Animals}

Mature tilapia, Oreochromis mossambicus, were obtained from the Tainan Branch of the Taiwan Fisheries Research Institute and kept under natural photoperiod at $27 \pm 1^{\circ} \mathrm{C}$ in a $180 \mathrm{l}$ closed circulating system in which freshwater was controlled to a constant condition. The condition of freshwater was $\mathrm{Na}^{+}, 0.23 \pm 0.01 \mathrm{mmol} \mathrm{l}^{-1} ; \mathrm{K}^{+}, 0.035 \pm 0.015$ $\mathrm{mmol} \mathrm{1}{ }^{-1} ; \mathrm{Ca}^{2+}, 0.17 \pm 0.03 \mathrm{mmol} \mathrm{l}^{-1} ; \mathrm{Mg}^{2+}$,
Table 1 . The average time schedule and main developmental feature of Oreochromis mossambicus at $26-28^{\circ} \mathrm{C}$

\begin{tabular}{ll}
\hline Hours after & Developmental feature \\
\hline $0-1$ & 1 cell \\
1.5 & 2 cells \\
2 & 4 cells \\
3 & 8 cells \\
4 & $16-32$ cells \\
12 & Blastula, appearance of \\
& melanophore on yolk sac \\
24 & Gastrula \\
36 & Heart beating \\
48 & Onset of blood circulation \\
60 & Appearance of melanophore \\
& on optic lobes \\
72 & Eye stage \\
96 & Hatching \\
\hline
\end{tabular}

$0.09 \pm 0.02 \mathrm{mmol}^{-1}$, which applied to all the freshwater used in this study. Fertilized eggs were retrieved from the mouths of females which had just started mouth-breeding (within $12 \mathrm{~h}$ after fertilization) as described previously (Hwang and $\mathrm{Wu}$ 1993). The fertilized eggs were incubated in aerated $1000 \mathrm{ml}$ bottles in a medium identical to that described above.

Embryos were dechorionated just before the $45 \mathrm{Ca}^{2+}$ tracer flux experiment or the digestion treatment. Dechorionation could not succeed until $48 \mathrm{~h}$ after fertilization and was conducted by tearing off the chorion with watchmaker forceps \# 5 under a stereomicroscope. Damage to the embryos from this procedure could be detected by the occurrence of yolk leaking, fading in body or yolk, or the cease of heart beating during the subsequent $8 \mathrm{~h}$ for flux measurement. Damaged embryos (less than $5 \%$ of the total number of the treated embryos) were discarded. The dechorionated embryos survived as well as the intact embryos if the incubation medium was not contaminated. The morphological development of embryos was checked under a stereomicroscope with appropriate lighting to determine the time sequence of different developmental stages (Table 1). Larvae were not fed during the experimental period. Samplings began $12 \mathrm{~h}$ after fertilization or hatching, and subsequent serial samplings were conducted at various stages of develop- 
ment. Twenty to thirty individuals of tilapia were collected as a pooled sample. Only the larvae used for weight measurement were anesthetized with 100 $\mathrm{mg} \mathrm{l}^{-1}$ MS222.

\section{Ion content in tissue and media}

Dechorionated embryos (intact embryos for day 1 after fertilization) were used for measurement of cation content. Pooled samplse of 20-30 embryos or larvae were briefly rinsed in deionized water, the solution on the body surface was wiped off, and the animals were subjected immediately to digestion with $5 \mathrm{ml}$ of $13.1 \mathrm{~N} \mathrm{HNO}_{3}$ and $10 \mathrm{ml}$ of $\mathrm{H}_{2} \mathrm{O}_{2}$ at $400^{\circ} \mathrm{C}$ for $15 \mathrm{~min}$ in a digestion apparatus (23130-20, Hach, USA). Digested solutions were diluted with a $0.2 \mathrm{~N} \mathrm{HCl}$ including $1.3 \% \mathrm{LaCl}_{3}$ for subsequent analysis. Water samples from incubation media were diluted with double-deionized water (Milli-RO60, Millipore, USA). Tissue, water samples as well as appropriate blanks were subjected to atomic absorption spectrophotometer (Z-8000, Hitachi, Japan) to measure $\mathrm{Ca}^{2+}, \mathrm{Na}^{+}$, $\mathrm{K}^{+}$and $\mathrm{Mg}^{2+}$ concentrations.

\section{${ }^{45} \mathrm{Ca}^{2+}$ tracer flux experiment}

$\mathrm{Ca}^{2+}$ influxes were determined by placing individual dechorionated embryos or larvae in aerated $50 \mathrm{ml}$ of ${ }^{45} \mathrm{Ca}^{2+}$-labelled (final concentration: 1 $\mu \mathrm{Ci} \mathrm{ml}{ }^{-1}$ ) medium for $8 \mathrm{~h}$ to allow the count rate to reach 5-10 times that of background. Animals were removed, washed in nonradioactive fresh water, homogenized and mixed with counting solution. The radio-activity of samples were determined on a liquid scintillation $\beta$-counter (Beckman, USA). Based on the assumptions that the specific radio-activity of bathing medium was constant and the backflux over the experimental period was negligible, the influx of $\mathrm{Ca}^{2+}$ was determined by the formula (Kirshner 1970):

$$
\mathrm{Q}_{\mathrm{emb}}=\mathbf{J}_{\text {in }} \cdot \mathrm{X}_{\mathrm{out}} \cdot \mathrm{t}
$$

$\mathrm{Q}_{\mathrm{emb}}$ : radio activity of embryo or larva (cpm per individual) at time $\mathrm{t} ; \mathrm{J}_{\text {in }}$ : influx (pmol individual ${ }^{-1}$ $\left.\mathrm{h}^{-1}\right) ; \mathrm{X}_{\text {out }}$ : specific activity of the incubation medium (cpm pmol $\left.{ }^{-1}\right)$; $t$ : time (h). $J_{\text {in }}$ was calculated from a slope, $J_{\text {in }} \cdot X_{\text {out }}$, which was derived from a simple linear regression of a plot of $Q_{e m b}$ against $t$.

For the measurement of $\mathrm{Ca}^{2+}$ efflux, newlyhatched larvae were incubated in slightly-aerated 50 ml of ${ }^{45} \mathrm{Ca}^{2+}$ freshwater (final concentration: 1 $\mu \mathrm{Ci} \mathrm{ml} l^{-1}$ ) for $24 \mathrm{~h}$. The larvae were removed from the medium, washed with nonradioactive freshwater for $5 \mathrm{~min}$, and then transferred into a beaker with $10 \mathrm{ml}$ nonradioactive freshwater. The medium in the beaker was pumped out and replenished with freshwater into the beaker at the same speed (about $2 \mathrm{ml} \mathrm{min}^{-1}$ ) to maintain the radioactivity in the medium low enough to eliminate a significant backflux of tracer into the animals. Water samples in the beaker were collected at certain periods. At the end of the experiment, the animals were sampled and treated as described in the influx experiment. The effluxes were determined as follows (Kirshner 1970):

$$
\ln Q_{\mathrm{emb}}=\left(\mathrm{J}_{\mathrm{out}} / \mathrm{Q}_{\mathrm{in}}\right) \cdot \mathrm{t}+\mathrm{C}
$$

$\mathrm{J}_{\text {out }}$ : efflux (pmol individual ${ }^{-1} \mathrm{~h}^{-1}$ ); $\mathrm{Q}_{\mathrm{in}}$ : total $\mathrm{Ca}^{2+}$ in the larva; $C$ : constant; $Q_{e m b}$ and t: the same as described before. As described above, $\mathrm{J}_{\text {out }}$ was obtained by calculating $J_{\text {out }} / Q_{\text {in }}$, which is the slope of a simple linear regression analysis of $\ln$ $\mathrm{Q}_{\mathrm{emb}}$ against $\mathrm{t}$.

Preliminary experiments have been conducted to confirm that $1 \mu \mathrm{Ci} \mathrm{ml}{ }^{-1}{ }^{45} \mathrm{Ca}^{2}+$ did not show significant effects on the development of embryos. Difference in quenching effect between water and tissue has been calibrated before calculting the data as described by Perry and Wood (1985).

\section{Scanning electron microscopy}

Embryos or larvae of different stages were immersion-fixed with $4 \%$ glutaraldehyde in phophate buffer (pH 7.4) at $4^{\circ} \mathrm{C}$ for $12 \mathrm{~h}$, dehydrated through a graded acetone series followed by drying with liquid $\mathrm{CO}_{2}$ on a critical point dryer (HCP-2, Hitachi, Japan). Dried samples were 


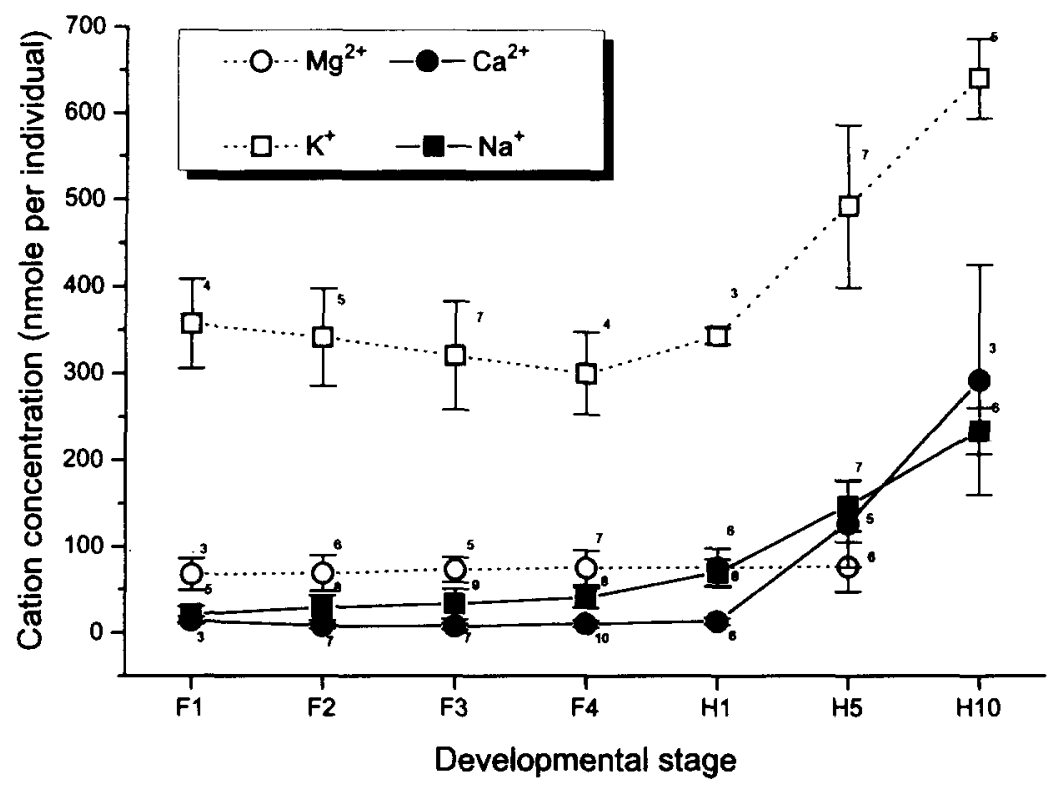

Fig. 1. Changes of whole-body cation contents with developmental stages. Mean, SEM, and N (small number) were indicated. F1-4, 1-4 days (i.e., 24-96 $\mathrm{h}$ after fertilization as indicated in Table 1) after fertilization; H1-10, 1-10 days after hatching.

mounted on an aluminum stub and coated with gold/palladium using an ion coater unit (IB-2, Giko, Japan). The specimens were observed on an Hitachi S-2500 scanning electron microscope.

\section{Results}

\section{Cation content of embryos and larvae}

Figure 1 shows the changes in the tissue content of four cations following the early development of tilapia. Tissue contents of $\mathrm{Na}^{+}, \mathrm{K}^{+}$and $\mathrm{Ca}^{2+}$ remained at a constant level during the embryonic stages and increased rapidly after hatching. Tissue $\mathrm{Na}^{+}$content did not show a significant change until 1 day after hatching, while significant changes did not appear in either $\mathrm{K}^{+}$or $\mathrm{Ca}^{2+}$ until 5 days after hatching (oneway ANOVA, Tukey's pairwise comparisons). Ten-day-old (i.e., 10 days after hatching) tilapia larvae had higher levels of tissue $\mathrm{Na}^{+}, \mathrm{K}^{+}$and $\mathrm{Ca}^{2+}$, about 8, 2, and 60 times that of the embryo, respectively. However, the level of tissue $\mathrm{Mg}^{2+}$ remained constant during the embryonic and larval stages (oneway ANOVA, Tukey's pairwise comparisons).

\section{$\mathrm{Ca}^{2+}$ influx and efflux}

As shown in Table 2, $\mathrm{Ca}^{2+}$ influx $\left(\mathrm{J}_{\text {in }}\right)$ increased following the development. There was less than 3-fold increase in $\mathrm{J}_{\text {in }}$ (in pmol individual ${ }^{-1} \mathrm{~h}^{-1}$ ) before hatching, while about 12 times the $J_{\text {in }}$ of $48 \mathrm{~h}$ postfertilization embryos was measured in the larvae 1 days after hatching.

Efflux of $\mathrm{Ca}^{2+}\left(\mathrm{J}_{\text {out }}\right)$ was only measured in 1-day-old larvae (120h after fertilization). The level of $\mathrm{J}_{\text {out }}$ was lower than that of $\mathrm{J}_{\text {in }}$ in the same brood of larvae, resulting in a significant net flux of $\mathrm{Ca}^{2+}$ (Table 3).

\section{Development of skin and chloride cell}

The skin of the $36 \mathrm{~h}$-postfertilization embryos was covered by mosaic pavement cells which were distinguished by their notable cell boundary. The surface of these pavement cells did not show any ridge structure or folding. Forty-eight hours after fertilization the surface of pavement cells showed some faint and irregular folding of the cell membranes (Fig. 2). This folding of the cell membranes increased rapidly following embryonic development. 
Table 2. $\mathrm{Ca}^{2+}$ influx of tilapia embryos and larvae

\begin{tabular}{|c|c|c|c|}
\hline $\begin{array}{l}\text { Hours after } \\
\text { fertilization }\end{array}$ & $\begin{array}{l}\mathrm{J}_{\text {in }} \text { (pmol } \\
\text { individual }^{-1} \mathrm{~h}^{-1}\end{array}$ & $\begin{array}{l}\mathbf{J}_{\text {in }}^{* *} \\
\left(\mathrm{pmol} \mathrm{mg}^{-1} \mathrm{~h}^{-1}\right.\end{array}$ & $\begin{array}{l}\text { Wet*** } \\
\text { Weight (mg) }\end{array}$ \\
\hline 48 & $\begin{array}{c}23.4 \pm 1.0 \\
(42)\end{array}$ & $5.9 \pm 0.3$ & 3.97 \\
\hline 72 & $\begin{array}{c}39.0 \pm 1.0 \\
(42)\end{array}$ & $9.8 \pm 0.3$ & 3.98 \\
\hline $96^{*}$ & $\begin{array}{c}58.8 \pm 1.4 \\
(63)\end{array}$ & $11.8 \pm 0.3$ & 4.98 \\
\hline 120 & $\begin{array}{c}286.8 \pm 20.0 \\
(63)\end{array}$ & $47.8 \pm 3.3$ & 6.00 \\
\hline
\end{tabular}

Mean \pm SEM (N) values are given; * Hatching; ** Calculated by dividing the $J_{\text {in }}$ (in pmol individual-1 $h^{-1}$ ) by the wet weight of embryos or larvae; *** Average of $10-15$ individuals

Table 3. Comparison of $\mathrm{Ca}^{2+}$ influx and efflux rates in 1-day-old (120 hours after fertilization) larvae of tilapia

\begin{tabular}{|c|c|c|c|c|c|}
\hline \multirow[b]{2}{*}{$\begin{array}{l}\text { Brood } \\
\text { no. }\end{array}$} & \multicolumn{4}{|c|}{ Measured data } & \multirow[b]{2}{*}{$\begin{array}{l}\text { Estimated } \\
\mathbf{J}_{\text {out }} / \mathbf{J}_{\text {in }} \text { ** }\end{array}$} \\
\hline & $\mathrm{J}_{\text {in }}^{*}$ & $\mathbf{J}_{\text {out }}{ }^{*}$ & $\begin{array}{l}\text { Net influx } \\
\left(\mathbf{J}_{\text {in }}-\mathrm{J}_{\text {out }}\right)\end{array}$ & $\mathrm{J}_{\text {out }} / \mathrm{J}_{\text {in }}$ & \\
\hline I & $67.3 \pm 2.5$ & $56.5 \pm 1.7$ & 10.8 & 0.84 & $13.2-15.8$ \\
\hline II & $28.3 \pm 0.8$ & $16.6 \pm 4.2$ & 11.7 & 0.59 & \\
\hline
\end{tabular}

* $\mathrm{J}_{\mathrm{in}}, \mathrm{J}_{\mathrm{out}}$, and net influx were expressed in pmol $\mathrm{mg}^{-1} \mathrm{~h}^{-1} ; * *$ Estimated flux ratio is based on diffusive movements of $\mathrm{Ca}^{2+}$ according to the formula:

$$
\mathrm{J}_{\text {out }} \mathrm{Ca}^{2+} / \mathrm{J}_{\text {in }} \mathrm{Ca}^{2+}=\left[\mathrm{Ca}^{2+}\right]_{\mathrm{j}} /\left[\mathrm{Ca}^{2+}\right]_{0} \exp (\mathrm{zFE} / \mathrm{RT})
$$

where $\left[\mathrm{Ca}^{2+}\right]_{\mathrm{i}}$ and $\left[\mathrm{Ca}^{+2}\right]_{0}, \mathrm{Ca}^{2+}$ concentration in plasma and external medium; $z$, valence; F, Faraday constant; E, transepithelial potential; R, gas constant: T, absolute temperature; Data of $\left[\mathrm{Ca}^{2+}\right]_{\mathrm{i}}$ and $\mathrm{E}$ cited from Pratap et al. (1989), Young et al. (1988), and McCormick et al. (1992).

In 72h-postfertilization embryos, the ridge structures (i.e., folding of cell membrane) were ramifying like labyrinth on the surface of pavement cells but still poorly developed near the center of the cell surface (Fig. 3). Ninety-six hours after fertilization the ramifying of ridges was more intensified and showed more regularity compared with that of the previous stage (Fig. 4, 5).

As reported in the previous study (Hwang 1989), most of the chloride cells are concentrated in the skin posterior to the pectoral fins. Therefore, observations were focused on this area of the tilapia embryos or larvae. No apical opening of chloride cell was found in the skin of the seven $36 \mathrm{~h}$ postfertilization embryos that have been studied. The first chloride cells were found in the skin of a 48h-postfertilization embryo after examining fifteen individuals. The number of chloride cell increased, and differentiation of cell structure progressed with the development of the skin (Fig. 3, 4). Typical microvilli-like structure of a chloride cell under SEM was evident in the apical opening of the cell (Fig. 3-5). About 2-3 chloride cells with surface area of $80 \times 132 \mu \mathrm{m}^{2}$ were observed in the skin near pectoral fins of newly-hatched larvae $(96 \mathrm{~h}$ after fertilization).

\section{Discussion}

Changes of tissue cation contents in the early developmental stages have been determined in several teleosts. Hayes et al. (1946) reported that developing salmon gained $\mathrm{Na}^{+}$and $\mathrm{Ca}^{2+}$ from the en- 


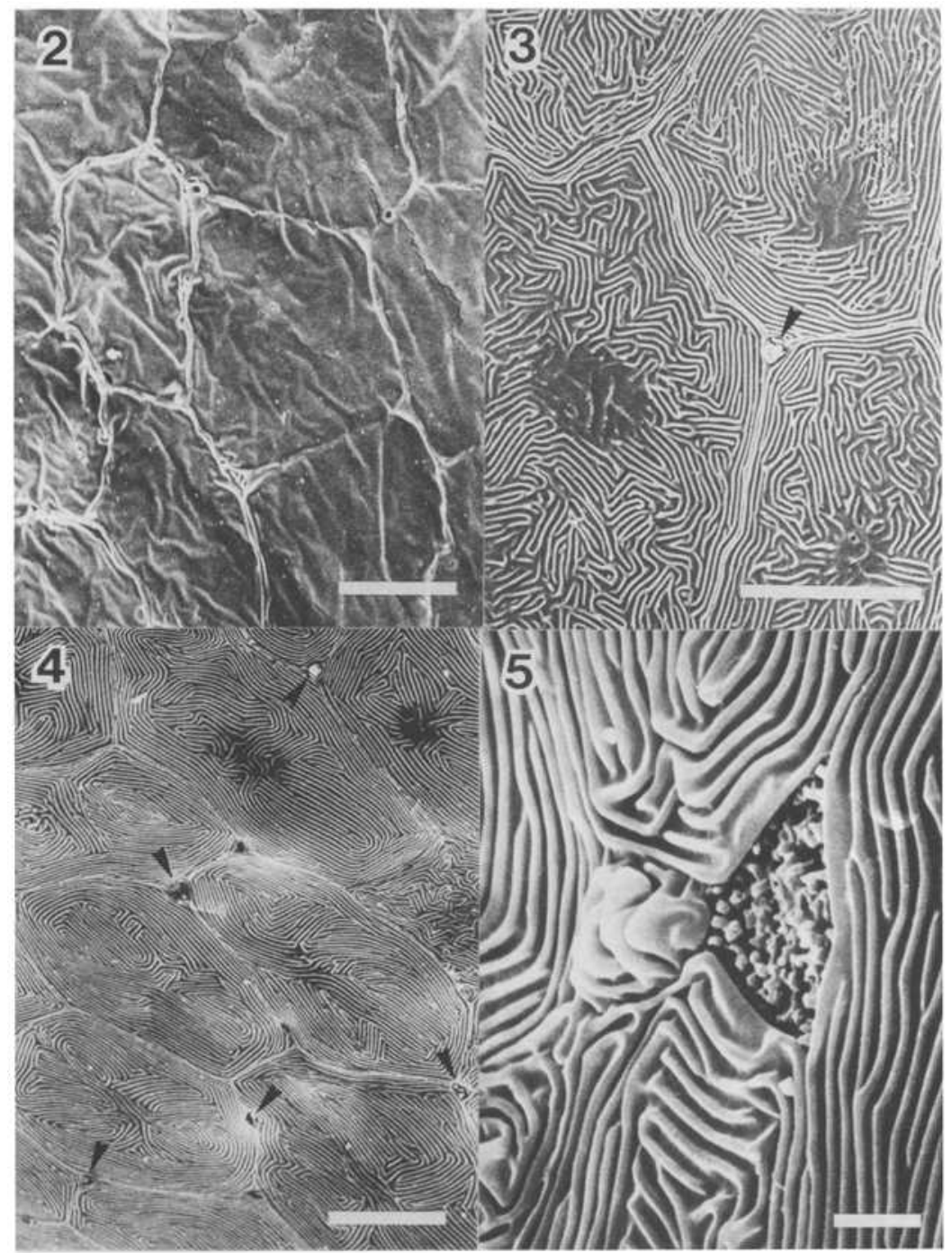

Fig. 2-5. Micrographs of scanning electron microscope observations on the skin of tilapia embryos with different ages.

Fig. 2. $48 \mathrm{~h}$ after fertilization. Skin surface looked like mosaic pavement due to notable cell boundary of pavement cells and showed some faint folding of cell membrane. (Scale $=10 \mu \mathrm{m}, \times 1,900$ ).

Fig. 3. $72 \mathrm{~h}$ after fertilization. Ridges (i.e., folding of cell membrane) were ramifying as labyrinth on the surface of pavement cells but still poorly developed near the center of cell surface. A chloride cell (arrow head) whose apical opening had numerous microvillus appeared at the boundary of three pavement cells. (Scale $=10 \mu \mathrm{m}, \times 2,900$ ).

Fig. $4.96 \mathrm{~h}$ after fertilization. Ramifying of ridge was intensified and showed more regularity comparing with that of the previous stage. More chloride cells (arrow heads) were observed. (Scale $=10 \mu \mathrm{m}, \times 1,900$ ).

Fig. $5.96 \mathrm{~h}$ after fertilization. Structure of well-developed ridge of pavement cells and microvilli in the apical opening of a chloride cell were noted. (Scale $=1 \mu \mathrm{m}, \times 13,400)$.

vironment after hatching but lost $\mathrm{K}^{+}$and $\mathrm{Mg}^{2+}$ to the outside. Seawater-adapted killifish (Fundulus heteroclitus) were found to have a gradual decrease in $\mathrm{K}^{+}$and a 2-2.5 fold increase in $\mathrm{Na}^{+}$from 4 days postfertilization till hatching (Guggino 1980b). Rombough and Garside (1984) also reported that Atlantic salmon (Salmo salar) showed a rapid increase in tissue $\mathrm{Na}^{+}, \mathrm{K}^{+}$and $\mathrm{Ca}^{2+}$ content following the development of alevins. In this study, tilapia revealed a constant level in tissue $\mathrm{Na}^{+}, \mathrm{K}^{+}$ 
and $\mathrm{Ca}^{2+}$ during the embryonic stages and a rapid increase after hatching, and a constant $\mathrm{Mg}^{2+}$ level throughout the embryonic and larval development. This observation was consistent, although not completely so, with that of Fu and Lock (1990) for the same species. The differences among the data of these studies may be ascribed to the difference in species or experimental design. However, this implies that there must be some mechanisms in the embryos to maintain the constancy of most cations including $\mathrm{Ca}^{2+}$.

The measured influx rate of $6-48 \mathrm{pmol} \mathrm{Ca}^{2+}$ $\mathrm{mg}^{-1} \mathrm{~h}^{-1}$ for tilapia embryos was near the range (27-146 pmol Ca $\mathrm{Ca}^{2} \mathrm{mg}^{-1} \mathrm{~h}^{-1}$ ) of those reported for several species of adult fish including tilapia (Fleming et al. 1973; Pang et al. 1980; Ichii and Mugiya 1983; Flik et al. 1985; Perry and Flik 1988). The $\mathrm{Ca}^{2+}$ influx rate in tilapia increased following the embryonic development, and the rate in the 1-day-old larvae turned out much higher than that in adult tilapia $\left(27.9\right.$ pmol $\left.\mathrm{mg}^{-1} \mathrm{~h}^{-1}\right)$. A similar phenomenon has been found in the flux rates of $\mathrm{Na}^{+}$and $\mathrm{Cl}^{-}$in seawater-adapted killifish (Guggibo $1980 \mathrm{~b}$ ) and in the drinking rates of herring (Clupea harengus), plaice (Pleuronectes platessa) and cod (Gadus morhua) (Tytler and Blaxter 1988; Mangor-Jensen and Adoff 1987), which has been ascribed to the larger surface-to-volume ratio of hatched larva than that of adults. This seems to also hold in tilapia, although the exact value of ratio in embryos or larvae of tilapia is unknown.

The chorion may contributed to some extent to the ion balance in freshwater fish embryos by concentrating cations in the perivitelline fluid and developing a potential difference across the chorion (Eddy et al. 1990; Peterson and Martin-Robichaud 1986). Guggino (1980a) found that water turnover rates were higher in the dechorionated killifish embryos than in the intact ones, however the rates of both groups showed a similar increase pattern following the development of embryos. Since dechorionated embryos were used in the present study, the $\mathrm{Ca}^{2+}$ influx rate of intact tilapia embryos is unknown; however, it is presumable to show a similar increase pattern as that of the dechorionated embryos.

The increase in $\mathrm{Ca}^{2+}$ influx with the embryonic and larval stages indicated that the mechanism of $\mathrm{Ca}^{2+}$ uptake is not fully developed at hatching but continues to progress during larval development. This increase may be the result of two possible factors: (1) increase of surface area of transporting epithelium, (2) increase of $\mathrm{Ca}^{2+}$ permeability. Flik et al. (1985) measured the whole-body $\mathrm{Ca}^{2+}$ influx rate in tilapia adult and concluded that gills, representing $70-80 \%$ of the total body surface, are the main site for more than $97.4 \%$ of extraintestinal $\mathrm{Ca}^{2+}$ entry in fish. Drinking in embryos or larvae, being in the range of adults as described above, may result in only a negligible fraction of the wholebody $\mathrm{Ca}^{2+}$ influx as that observed in tilapia adult (Flik et al. 1985). Since tilapia start to develop gills at hatching, the skin is probably the main surface for $\mathrm{Ca}^{2+}$ entry in tilapia embryos before the complete development of gills. Besides the elongation of embryos, the differentiation of skin surface and the development of chloride cells during embryonic and larval stages also provides morphological evidence for the increase of surface area for $\mathrm{Ca}^{2+}$ transport. It has been suggested that ridges create local water turbulence and increase surface area for respiration (Olson and Fromm 1973). At hatching, development of gills, including filaments and lamellae, greatly increase the surface area of the whole fish. Consequently, a 7-fold increase of $\mathrm{Ca}^{2+}$ influx (in pmol individual ${ }^{-1} \mathbf{h}^{-1}$ ) occurred around hatching in tilapia. Whether changes in $\mathrm{Ca}^{2+}$ permeability with embryonic and larval development in tilapia contribute to the increase of $\mathrm{Ca}^{2+}$ influx remains to be verified. However, Guggino (1980a) suggested that the increase in water turnover around hatching may be attributed more to an increase in the surface-to-volume ratio than to a change in the water permeability of the epithelia.

Similar to the $\mathrm{Ca}^{2+}$ influx rate described above, the $\mathrm{Ca}^{2}+$ efflux rate in 1-day-old larvae was higher than that reported for the adults of tilapia, 11.5 pmol mg ${ }^{-1} \mathrm{~h}^{-1}$, (Flik et al. 1985) and eel (Anguilla

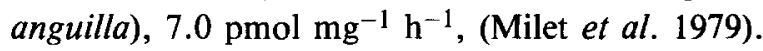
This may also be ascribed to the larger surface-tovolume ratio in hatched larvae. The $\mathrm{Ca}^{2}+$ influx rate was about $1.2-1.7$ times the value of $\mathrm{Ca}^{2+}$ efflux rate in 1-day-old tilapia larvae, resulting in a significant net uptake of $\mathrm{Ca}^{2+}$ as reported in the 
adult (Flik et al. 1985). This net uptake could account for the rapid increase in tissue $\mathrm{Ca}^{2}+$ content after hatching, reflecting a physiology demand of $\mathrm{Ca}^{2}+$ for bone formation or other metabolism during the larval development.

According to the Ussing flux ratio equation (Ussing 1949), if the estimated ratio for $\mathrm{Ca}^{2+}$ passive movement is higher than the measured ratio, then the movement of $\mathrm{Ca}^{2+}$ is active. $\left[\mathrm{Ca}^{2+}\right]_{i}$ and $\mathrm{E}$ (Table 3) in tilapia hatched larvae were unavailable in the present study and were assumed to be close to the plasma $\mathrm{Ca}^{2+}$ concentration, $2.5 \mathrm{mM}$, (Pratap et al. 1989) and the transepithelial potential of whole animal or isolated opercular membrane, 3-13 mV, in tilapia adults (Young et al. 1988; McCormick et al. 1992). $\left[\mathrm{Ca}^{2+}\right]_{0}$ and $\mathrm{T}$ of the present study were $0.2 \mathrm{mM}$ and $299^{\circ} \mathrm{K}$, respectively. Thus, the estimated ratio was much higher than those measured (Table 3). The measured ratios derived from the present study were similar to that reported in the freshwater trout, 0.54 , although the estimated ratio for the trout was lower, 2.19 , due to the difference in $\left[\mathrm{Ca}^{2+}\right]_{i}$ and $E$ (Perry and Flik 1988). It is reasonable to state that active transport is involved in the uptake of $\mathrm{Ca}^{2+}$ in embryos and larvae of tilapia as demonstrated in the adult trout (Perry and Flik 1988), since the $\left[\mathrm{Ca}^{2+}\right]_{i}$ and $\mathrm{E}$ have to be lower than $0.13 \mathrm{mM}$ and $-154 \mathrm{mV}$, respectively, to exclude the possibility of active transport.

Chloride cells have been well documented to be responsible for the active transport of $\mathrm{Ca}^{2+}$ in adult fish (Payan et al. 1981; Perry and Wood 1985; Perry and Flik 1988; Marschall et al. 1992; McCormick et al. 1992; Perry et al. 1992). Embryos or larvae of teleosts have been found to develop chloride cells in the skin until their gills are fully formed and functioning (Hwang and Hirano 1985; review of Alderdice 1988; Hwang 1989, 1990). The structure and function of these cells have been demonstrated to be similar to that of the gill chloride cells in adults, i.e., the excretion of ions (Hwang and Hirano 1985; Hwang 1990). As described above, the main surface responsible for $\mathrm{Ca}^{2+}$ flux before the development of gills is the skin, in which only chloride cells showed a typical structure for active transport, i.e., numerous mitochondria, wellbranched tubular system and an apical opening ex- posed to ambient medium (Hwang and Hirano 1985; Hwang 1989, 1990). It is reasonable to assume that skin chloride cells are the site which performs the active uptake of $\mathrm{Ca}^{2+}$ in embryos and larvae.

In summary, tilapia maintained a constant level of $\mathrm{Ca}^{2+}$ content during the embryonic stages and had a rapid increase of $\mathrm{Ca}^{2}+$ content after hatching through an increasing uptake of $\mathrm{Ca}^{2+}$ from the environment, and the active transport via skin chloride cells is probably involved in this mechanism.

\section{Acknowledgements}

This study was financially supported by National Science Council (Grant no.: NSC-81-0209-B001-07 and NSC-82-0211-B-001-009). The authors thank Dr. H.C. Lin for her critical reading of the manuscript.

\section{References cited}

Alderdice, D.F. 1988. Osmotic and ionic regulation in teleost eggs and larvae. In Fish Physiology. Vol. XI, part A, pp. 163-251. Edited by W.S. Hoar and D.J. Randall. Academic Press, San Diego.

Brown, D.J.A. and Lynam, S. 1981. The effect of sodium and calcium concentrations on the hatching of eggs and the survival of the yolk sac fry of rainbow trout, Salmo trutta L. at low pH. J. Fish Biol. 19: 205-211.

Eddy, F.B. 1982. Osmotic and ionic regulation in captive fish with particular reference to salmonids. Comp. Biochem. Physiol. 73B: $125-141$.

Eddy, F.B., Ward, M.R., Talbot, C. and Primmett, D. 1990. Ionic movement across the chorion in newly shed saimon eggs (Salmo salar L.). J. Comp. Physiol. 159B: 771-776.

Fleming, W.R., Brehe, J. and Hanson, R. 1973. Some complicating factors in the study of the calcium metabolism of teleosts. Am. Zool. 13: 793-797.

Flik, G., Fenwick, J.C., Kolar, Z., Mayer-Gostan, N. and Wendelaar Bonga, S.E. 1985. Whole-body calcium flux in cichlid teleost fish (Oreochromis mossambicus) adapted to freshwater. Am. J. Physiol. 249: R432-437.

Fu, H. and Lock, R.A.C. 1990. Pituitary response to cadmium during the early development of tilapia (Oreochromis mossambicus). Aquat. Toxicol. 16: 9-18.

Guggino, W.B. 1980a. Water balance in embryos of Fundulus heteroclitus and $F$. bermudae adapted to sea water. Am. J. Physiol. 238R: 36-41. 
Guggino, W.B. 1980b. Salt balance in embryos of Fundulus heteroclitus and $F$. bermudae adapted to sea water. Am. J. Physiol. 238R: 42-49.

Hayes, F.R., Darcy, D.A. and Sullivan, C.M. 1946. Changes in the inorganic constituents of developing salmon eggs. J. Biol. Chem. 163: 621-631.

Hwang, P.P. 1989. Distribution of chloride cells in teleost larvae. J. Morphol. 200: 1-8.

Hwang, P.P. 1990. Salinity effects on development of chloride cells in the larvae of ayu, Plecoglossus altivelis. Marine Biol. 107: 1-7.

Hwang, P.P. and Hirano, R. 1985. Effects of environmental salinity on intercellular organization and junctional structure of chloride cells in early stages of teleost development. J. Exp. Zool. 236: 115-126.

Hwang, P.P., Lin, S.W. and Lin, H.C. 1994. Different sensitivities to cadmium in tilapia larvae (Oreochromis mossambicus; Teleostei). Arch. Environ. Contam. Toxicol. (In press).

Hwang, P.P. and Wu, S.M. 1993. Role of cortisol in hypoosmoregulation in larvae of the tilapia (Oreochromis mossambicus). Gen. Comp. Endocrinol. 92: 318-324.

Ichii, T. and Mugiya, Y. 1983. Effects of a dietary deficiency in calcium on growth and calcium uptake from the aquatic environment in the goldfish, Carassius auratus. Comp. Biochem. Physiol. 77A: 259-262.

Kirshner, L.B. 1970. The study of $\mathrm{NaCl}$ transport in aquatic animals. Am. J. Zool. 10: 365-376.

Lee, C.S. and Hu, F. 1983. Influences of Ca and $\mathrm{Mg}$ ions on the egg survival of grey mullet, Mugil cephalus L.J. Fish Biol. 22: 13-20.

Mangor-Jensen, A. and Adoff, G.R. 1987. Drinking activity of newly hatched larvae of cod (Gadus morhua L.). Fish Physiol. Biochem. 3: 99-103.

Marshall, W.S., Bryson, S.E. and Wood, C.M. 1992. Calcium transport by isolated skin of rainbow trout. J. Exp. Biol. 166: 297-316.

McCormick, S.D., Hasegawa, S. and Hirano, T. 1992. Calcium uptake in the skin of a freshwater teleost. Proc. Nat. Acad. Sci. U.S.A. 89: 3635-3638.

Milet, C., Peignoux-Deville, J. and Martelly, E. 1979. Gill calcium fluxes in the eel, Anguilla anguilla (L). Effects of Stannius corpuscles and ultimobranchial body. Comp. Biochem. Physiol. 63A: 63-70.

Oslon, K.R. and Fromm, P.O. 1973. A canning electron microscopic study of secondary lamellae and chloride cells of rainbow trout (Salmo gairdneri). Z. Zellforsch. Microsk. Anat. 143: 439-449.

Pang, P.K.T., Griffith, R.W., Maetz, J. and Pic, P. 1980. Calcium uptake in fishes. In Epithelial Transport in the Lower Vertebrates. pp. 120-132. Edited by B. Lahlou. Cambridge University Press, Cambridge.

Payan, P., Mayer-Gostan, N. and Pang, P.K.T. 1981. Site of calcium uptake in the freshwater trout gill. J. Exp. Zool. 216: 345-347.

Perry, S.F. and Flik, G. 1988. Characterization of branchial transepithelial calcium fluxes in freshwater trout, Salmo gairdneri. Am. J. Physiol. 254: R491-498.

Perry, S.F., Goss, G.G. and Fenwick, J.C. 1992. Interrelationships between gill chloride cell morphology and calcium uptake in freshwater teleosts. Fish Physiol. Biochem. 10: 327-337.

Perry, S.F. and Wood, C.M. 1985. Kinetics of branchial calcium uptake in the rainbow trout: effects of acclimation to various external calcium levels. J. Exp. Biol. 116: 411-433.

Peterson, R.H., Martin-Robichaud, D.J. 1986. Perivitelline and vitelline potentials as influenced by ambient ionic strength, natal salinity, and electrode electrolyte; and the influence of these potentials on cadmium dynamics within the egg. Can. J. Fish. Aquat. Sci. 43: 1445-1450.

Pratap, H.B., Fu, H., Lock, R.A.C. and Wendelaar Bonga, S.E. 1989. Effect of waterborne and dietary cadmium on plasma ions of the teleost, Oreochromis mossambicus, in relation to water calcium levels. Arch. Environ. Contam. Toxicol. 18: 568-575.

Rombough, P.J. and Garside, E.T. 1984. Disturbed ion balance in alevin of Atlantic salmon, Salmo salar, chronically exposed to sublethal concentrations of cadmium. Can. J. Zool. 62: 1443-1450.

Tytler, P. and Blaxter, J.H.S. 1988. The effects of external salinity on the drinking rates of the larvae of herring, plaice and cod. J. Exp. Biol. 138: 1-15.

Ussing, H.H. 1949. Distinction by means of tracers between active transport and diffusion. The transfer of iodide across the isolated frog skin. Acta Physiol. Scand. 19: 43-56.

Young, P.S., McCormick, S.D., Demarest, J.R., Lin, R.J., Nishioka, R.S. and Bern, H.A. 1988. Effects of salinity, hypophysectomy, and prolactin on whole-animal transepithelial potential in the tilapia Oreochromis mossambicus. Gen. Comp. Endocrinol. 71: 389-397. 